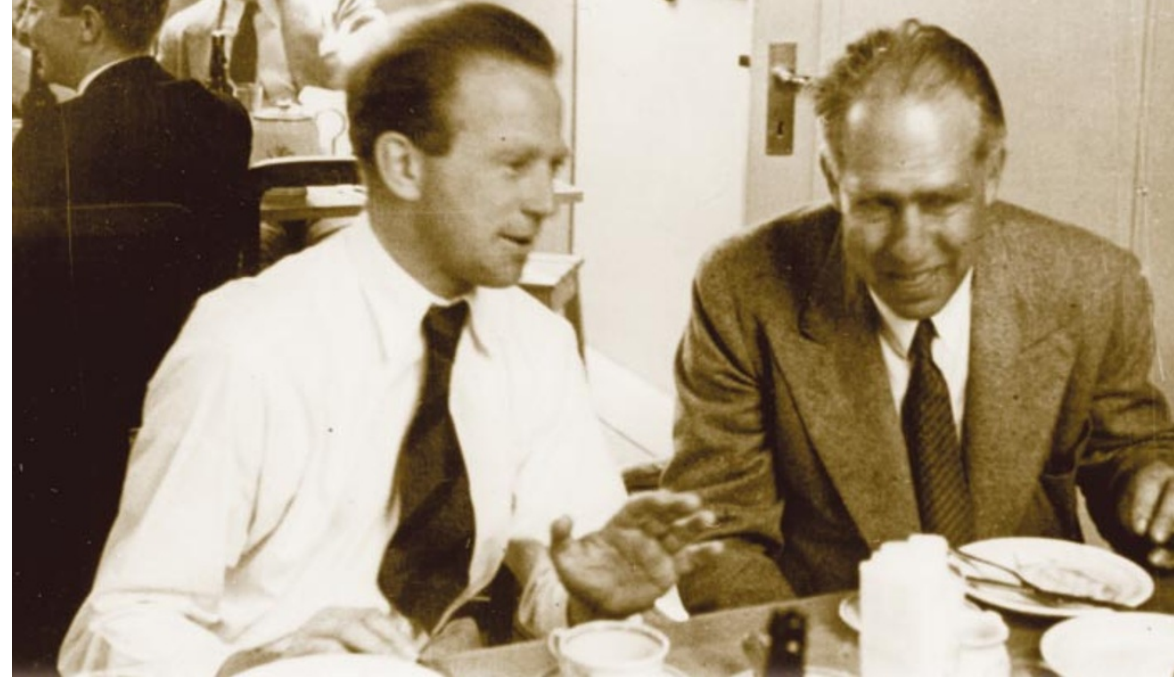

handling bioterror agents shoots up.

But security may not be of equal concern for all hazardous biological agents, argues Steven Block, a biophysicist at Stanford University in California and a member of the JASON group, which advises the government on technical issues related to defence. Whereas the smallpox virus may be hard to come by, he points out, deadly microbes such as Escherichia coli O157:H7, which can contaminate food, the bacterium Francisella tularensis, responsible for tularaemia, which flared up two years ago in Kosovo, and even the bacterium that causes anthrax, Bacillus anthracis, can be readily obtained from nature.

This distinction may soon be enshrined in law. A bill sponsored by Senators Edward Kennedy (Democrat, Massachusetts) and Bill Frist (Republican, Tennessee) instructs the health department to work with scientists in drawing up a new list of biological agents that should be subject to tight regulation. Ron Atlas, president-elect of the American Society for Microbiology, says he would hope for a hierarchy of security requirements that would take the varying risk of different agents into account.

Block and others point out that most biological agents pose only a limited threat without the technology to turn them into weapons them. But research into this would also expand under the Bush budget plan, which includes $\$ 600$ million in new funding related to bioterrorism at the Department of Defense. Part of this would fund studies of "how potential bioterrorism pathogens may be weaponized, transported, and disseminated", according to a budget fact sheet distributed by the White House.

From an international perspective, the Bush biodefence plan is part of a worldwide trend towards greater funding of biodefence research, says Jean Pascal Zanders of the Stockholm International Peace Research Institute. At least 12 countries, including Sweden, already have high-containment facilities, known as biosafety level 4 labs, and several others are expected to announce plans this year to build their own, Zanders says. "We could get a sort of arms race on the defensive side," he says, "and it might spill over into an offensive one."

Happier times: Bohr (right), who regarded Heisenberg almost as a son, later wrote him angry letters.

\title{
Physicist's letters reveal clues to bitter wartime rift
}

\section{Alison Abbott, Munich}

Unsent letters written by Danish physicist Niels Bohr to his German protégé Werner Heisenberg saw the light of day for the first time on 6 February. But the long-awaited publication has failed to solve the mystery of what happened during their unhappy meeting in Nazi-occupied Copenhagen.

Heisenberg, who headed Germany's unsuccessful attempt to produce a nuclear bomb, visited Bohr in September 1941 with a colleague, Carl Friedrich von Weizsäcker, on a cultural-exchange mission to Copenhagen.

Heisenberg and Bohr went for a walk together, during which Heisenberg brought up the subject of the German nuclear-bomb programme. There is no consensus as to what exactly was said, or what Heisenberg's motive for the visit had been - whether he was trying to recruit Bohr to the German programme, trying to find out how far the Allies had progressed in their attempts to build an atomic bomb, or taking the first steps towards a moratorium against nuclear weapons. All that is known is that the incident caused a deep rift between them. The mystery formed the basis of Michael Frayn's successful play Copenhagen.

The newly published letters and notes were written between 1957 and 1962. After the war, Heisenberg claimed that he had wanted to discuss with Bohr the prospect of a worldwide moratorium on bomb development programmes, and moreover that he had deceived the Nazi regime into believing that a bomb was not technically possible.

But in one letter, Bohr says he remembered Heisenberg telling him "everything was being done in Germany to develop atomic weapons" and that Heisenberg "had spent the last two years working more or less exclusively on such preparations". In another, Bohr writes: "It is therefore quite incomprehensible to me that you should think that you hinted to me that German physicists would do all they could to prevent such an application of atomic science."

Immediately after reading the letters, von Weizsäcker, whose brother Richard was the German president in 1984-94, told the German Press Agency that Bohr's memories "contained deep errors". In an interview with the Munich newspaper Süddeutsche Zeitung, he said that Heisenberg had indeed been on a peace mission to promote a bomb moratorium, albeit prompted partly by selfinterest. Because Germany had given up its own programme, Heisenberg and von Weizsäcker wanted the Allies to do the same, "so that a bomb wouldn't fall on us".

Very few of the facts and viewpoints put forward are totally new to historians, but Finn Aaserud, director of the Niels Bohr Archive in Copenhagen, points out that they indicate the depth of agitation of the scientists involved. "Bohr clearly worried very intensely about it — he had, after all, considered Heisenberg as a sort of son." Thomas Powers, who wrote Heisenberg's War: The Secret History of the German Bomb, the book on which Copenhagen was based, agrees. "For the first time we have a clearer insight into what made Bohr so angry," he says.

Aaserud also notes that Bohr's letters were written during the cold war, many years after the meeting, and that seeds of doubt about Heisenberg's motivation could have been planted by the questions asked him by intelligence services and historians.

Helmut Rechenberg, head of the Heisenberg Archive in Munich, and one of Heisenberg's past pupils, comments that the letters show how much Bohr wanted to discuss with Heisenberg the meeting that disrupted their relationship. "And that's a pity, because Heisenberg told me, and others, that he wanted very much to discuss it with Bohr," says Rechenberg. Bohr's death in 1962 made this impossible.

t w w w.nbi.dk/ NBA/ papers/introduction.htm 